\title{
Phospholipids of the Rotifer, Prawn, and Larval Fish*1
}

\author{
Shin-ichi Teshima, ${ }^{* 2}$ Akio Kanazawa, ${ }^{* 2}$ Koji Horinouchi, ${ }^{* 2}$ \\ Shigehisa Yamasaki, ${ }^{* 2}$ and Hachiro Hirata*2 \\ (Accepted July 17, 1986)
}

\begin{abstract}
In order to define the nutritional role of dietary phospholipids (PL) in larval fish, the PL classes and possible fatty acid combinations of phosphatidylcholine (PC) were investigated on the food organisms such as the micro-algae and rotifers Brachionus plicatilis, post-larval prawns (P-30) Penaeus japonicus, and larval fish. PC and phosphatidylethanolamine were the major PL classes in a marine Chlorella $(\mathrm{CH})$, Tetraselmis (TS), rotifers cultured with either $\mathrm{CH}$ or TS, red sea bream (40-days old) Chrysophrys major, knife jaw (30 days-old) Oplegnathus fasciatus, Ayu (74-days old) Plecoglossus altivelis, and prawn. The major $\mathrm{PC}$ in the larval fish and prawn were those having fatty acid combinations of $\mathrm{C}_{18} \mathrm{C}_{20}$ (mainly $\mathrm{C}_{16: 0} \mathrm{C}_{20 ; 5 \omega 3}$ ), $\mathrm{C}_{18} \mathrm{C}_{22}$ (mainly $\mathrm{C}_{18: 0} \mathrm{C}_{22: 8 \omega 3}$ ), and $\mathrm{C}_{18} \mathrm{C}_{22}$ (mainly $\mathrm{C}_{18: 0} \mathrm{C}_{22: 8 \omega 3}$ and/or $\mathrm{C}_{18: 1 \omega \theta} \mathrm{C}_{22: 6 \omega 3}$ ). Because larval fish are incapable of de novo synthesis of $\omega 3$ - and $\omega 6$-series of fatty acids and also possibly have a limited ability for the synthesis of some PC, a part of these PC occurring in the larval fish may be derived from food organisms such as the rotifers which contained $P C$ with fatty acid combinations of $\mathrm{C}_{10} \mathrm{C}_{20}$ (mainly $\mathrm{C}_{16: 0} \mathrm{C}_{20: 5 \omega 8}$ ).
\end{abstract}

Recent our work has shown that some dietary phospholipids (PL) are necessary for good growth and survival of the larval fish such as the red sea bream Chrysophrys major, ${ }^{1,2)}$ the Ayu Plecoglossus altivelis, ${ }^{8,4)}$ the starry flounder Paralichthys olivaceus (Unpublished data), and the knife jaw Oplegnathus fasciatus. ${ }^{2)}$ These findings are unusual because animals in general can synthesize phospholipids from dietary or endogenous fatty acids, diglycerides, and triglycerides. Kanazawa et al. ${ }^{* 3}$ found that phosphatidylcholine (PC) and phosphatidylinositol (PI) containing unsaturated fatty acids such as linoleic acid $(18: 2 \omega 6)$, docosahexaenoic acid (22: $6 \omega 3$ ), etc. as fatty acid moieties were effective in enhancing growth and survival rates of the larval Ayu.

The importance of inclusion of dietary PL in diets has also been shown on the crustaceans such as the prawn Penaeus japonicus ${ }^{5-7)}$ and the lobster Homarus americanus. ${ }^{8,8)}$ Recently, we have demonstrated that the retardation of growth in the prawn $P$. japonicus receiving a PL-deficient diet is probably attributable to the insufficient transport of dietary lipids, especially cholesterol which is one of essential nutrients. ${ }^{10-18)}$ Regarding the larval fish, however, little is known on the mecha- nism by which dietary PL exert a growth-enhancing effect.

Generally, larval fish grow well on a live food such as the rotifers. ${ }^{14,152}$ The manifestation of PL components of food organisms and predators may provide an understanding of the modification, transport, and storage of dietary PL in the larval fish. As part of defining the nutritional role of supplemental PL in diets, we investigated the compositions of PL classes and molecular species of PC in several food organisms, larval fish, and post-larval prawn.

\section{Materials and Methods}

\section{Culture of Food Organisms}

The micro-algae, Chlorella saccharophila (a marine Chlorella) and Tetraselmis tetrathele, were cultured outdoors at $28 \pm 2^{\circ} \mathrm{C}$ in $500 l$-round transparent tanks containing $20 \%$ or $35 \%$ sea water with the following fertilizers $(\mathrm{g} / \mathrm{t})^{16)}$ : Ammonium sulfate, 5 ; super phosphate lime, 15 ; urea, 5; Clewat-32 (Teikoku-kagaku Co.), 5. The algae were harvested in the end of logarithmic growth-phase (population density: Chlorella, 10.3 $\times 10^{8}$ cells $/ \mathrm{ml}$; Tetraselmis, $0.26 \times 10^{8}$ cells $/ \mathrm{ml}$ ).

*1 This work was orally presented at the Annual Meeting of the Japanese Society of Scientific Fisheries, April, 1986, Tokyo.

*2 Faculty of Fisheries, University of Kagoshima, 50-20 shimoarata-4, Kagoshima, 890, Japan (手鼠新一,

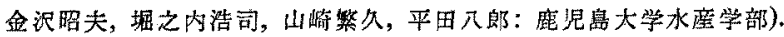

*3 Presented at the meeting of the Japanese Society of Scientific Fisheries, held in Tokyo, April, 1983. (Ab. stracts p. 39). 
Three types of the algae were used for the culture of rotifers Brachionus plicatilis: (1) Chlorella culture in 20\%o sea water [CH(20\%o)]; (2) Chlorella culture in $35 \%$ sea water $[\mathrm{CH}(35 \%)$ ) ; (3) Tetraselmis cultured in $20 \%$ sea water [TS $(20 \% o)$ ]. When Chlorella and Tetraselmis bloomed up to the densities of $15 \times 10^{\circ} \mathrm{cells} / \mathrm{m} l$ and $0.16 \times 10^{8}$ cells $/ \mathrm{m} l$, respectively, the rotifers were inoculated at the concentration of 5 individuals $/ \mathrm{m} l$ water. The rotifers were cultured outdoors in 1 tonpolycarbonate tanks at $21-29^{\circ} \mathrm{C}$ for 4 days until they were increased to the population density of $30-40$ individuals $/ \mathrm{ml}$. In this paper, the rotifers cultured with $\mathrm{CH}(20 \%), \mathrm{CH}(35 \%)$, and $\mathrm{TS}(20 \%)$ were abbreviated as $\mathrm{CH}(20 \%)$-rotifer, $\mathrm{CH}(35 \%)$ rotifer, and TS $(35 \% 0)$-rotifer, respectively.

\section{Larval Fish and Post-larval Prawn}

The red sea bream (30-days old), knife jaw (30days old), and Ayu (74-days old) were obtained from the Fisheries Experimental Station of Oita Prefecture. After hatching, the red sea bream and knife jaw were maintained on the rotifers cultured with a marine Chlorella ( $\mathrm{CH}$-rotifer), whereas the Ayu received a combination of $\mathrm{CH}$-rotifer, Artemia, and a commercial diet. The post-larval prawn (P-30) was produced in our laboratory by feeding a combination of micro-particulate diets ${ }^{17}$ ) and Artemia nauplii.

\section{Separation and Analysis of Lipid Components}

Total lipids (TL) were extracted with chloroform-methanol-water ${ }^{18)}$ and separated into neutral lipids (NL) and PL by column chromatography on Kieselgel 60 as described previously. ${ }^{10)}$ PL were further separated into PL classes by thinlayer chromatography (TLC) on Kieselgel $\mathrm{H}$ containing sodium carbonate with chloroformmethanol-acetic acid-water $(25: 15: 2: 0.5)$ and then quatitated photometrically. ${ }^{10)}$ After TLC, PC fraction was eluted from the TLC plates with chloroform-methanol-14N ammonia $(56: 48: 2)$ for the estimation of molecular species. ${ }^{10)}$

\section{Gas-liquid Chromatography (GLC)}

GLC was conducted using a Shimadzu GC-8A with a hydrogen flame ionization detector. Fatty acid compositions (\%) of PC before and after catalystic hydrogenation with a platinum black were determined by GLC on $5.0 \%$ Shinchrom E-71 (column temp. $215^{\circ} \mathrm{C}$ ) ${ }^{1 \theta}$ ) The hydrogenates of diglycerides (DG) were converted to trimethylsilyl (TMS) derivatives with hexamethyldisilazane and trimethylchlorosilane. The TMS derivatives of DG were subjected to GLC on $1.5 \%$ OV-1 on Shimalite W (AW, DMCS, 80-100 mesh) (glass column $50 \mathrm{~cm} \times 3 \mathrm{~mm}$ i.d., column temp. $230^{\circ} \mathrm{C}$ to $300^{\circ} \mathrm{C}$ at an increasing rate of $2^{\circ} \mathrm{C} / \mathrm{min}$ ) for determination of total carbon numbers of fatty acyl chains in $\mathbf{P C}^{20}$ Dipalmitin (Sigma Chem. Co.), distearin (Sigma Chem. Co.), diarachidin (Nu Chek Prep. Inc.), and dibehenin (Nu Chek Prep. Inc.) were used as standards.

\section{Estimation of Possible Fatty Acid Combinations in $P C$}

The possible fatty acid combinations in PC were estimated by the method of Ohshima et al. ${ }^{20)}$ PC fraction was converted to 1,2-diglycerides (1,2DG) by hydrolysis with phospholipase $\mathrm{C}$ (EC 3.1.4.3). The resultant 1,2-DG were extracted with chloroform-methanol and purified by TLC on Kieselgel $G$ with hexane-ether-acetic acid (80: $30: 1)$. Possible fatty acid combinations of PC were estimated from the fatty acid compositions $(\%)$ before and after hydrogenation and the PC compositions $(\%)$ based on total carbons in fatty acyl chains.

\section{Results}

\section{Lipid Contents and PL Class Compositions}

Table 1 shows the TL, NL, and PL contents, and PL class compositions of the marine Chlorella, Tetraselmis, rotifers, larval fish, and prawn (P-30). The Chlorella, Tetraselmis, and rotifers contained TL ranging from $8.06 \%$ to $12.13 \%$ of dry matters and PL amounting to $28.4-37.5 \%$ of TL. The PL of the micro-algae and rotifers were composed of PC $(41.7-47.1 \%$ of total PL), phosphatidylethanolamine (PE) (34.5-39.0\%), PI (7.3-11.1\%), and phosphatidylserine (PS) $(1.6-6.7 \%)$ as the prominent PL classes. The proportions of PL classes of the micro-algae and rotifers thus resembled each other.

The larval fish such as the red sea bream, knife jaw, and Ayu, and the post-larval prawn contained TL ranging from $0.96 \%$ to $3.5 \%$ and $P L$ amounting to $34.7-43.4 \%$ of TL. These animals gave similar PL class compositions each other and contained PC (43.3-48.8\%) and PE (30.5-32.6\%) as the major PL classes as observed in the $\mathrm{CH}(20 \%)$, $\mathrm{CH}(35 \%)$, and $\mathrm{TS}(20 \%)$-rotifers.

\section{Fatty Acid Compositions of $P C$}

Table 2 shows the fatty acid compositions of soybean lecithin and PC from the Chlorella, Tetraselmis, rotifers, larval fish, and prawn. 
Table 1. Total lipid, neutral lipid, and phospholipid class contents of the food organisms, larval fish, and post-larval prawn $P$. japonicus

\begin{tabular}{|c|c|c|c|c|c|c|c|c|c|c|}
\hline \multirow[t]{2}{*}{ Organism*1 } & \multicolumn{3}{|c|}{$\begin{array}{c}\text { Content } \\
\left(\% \text { of dry or fresh } w_{2}\right) * 2\end{array}$} & \multicolumn{7}{|c|}{$\begin{array}{c}\text { Composition } \\
(\% \text { of total phospholipids) })^{* 3}\end{array}$} \\
\hline & TL & NL & PL & PE & PS & PI & $\mathrm{PC}$ & SM & LPC & UK \\
\hline Marine Chlorella $[\mathrm{CH}(20 \%)]$ & 8.06 & 5.77 & $2.29(28.5 \%)^{* 4}$ & 34.5 & 1.6 & 11.1 & 47.1 & 1.2 & 1.6 & 2.9 \\
\hline Tetraselmis [TS $(20 \%)]$ & 8.35 & 5.97 & $2.37(28.4 \%)$ & 38.6 & 2.1 & 9.1 & 45.7 & 1.0 & 1.3 & 2.2 \\
\hline $\mathrm{CH}(20 \%)$-rotifer & 10.75 & 6.72 & $4.03(37.5 \%)$ & 37.4 & 5.0 & 11.1 & 41.9 & 3.4 & 1.2 & - \\
\hline $\mathrm{CH}(35 \%)$-rotifer & 12.13 & 7.64 & $4.49(37.0 \%)$ & 39.0 & 3.4 & 10.4 & 42.1 & 2.9 & 2.2 & - \\
\hline TS $(20 \%)$-rotifer & 11.41 & 7.11 & $4.30(37.7 \%)$ & 37.3 & 6.7 & 7.3 & 41.7 & 2.7 & 4.3 & - \\
\hline Red sea bream ( 30 days old) & 1.85 & 1.18 & $0.67(36.3 \%)^{* 4}$ & 32.6 & 10.1 & 5.2 & 43.3 & 4.1 & 4.7 & - \\
\hline Knife jaw ( 30 days old) & 1.70 & 0.97 & $0.73(42.8 \%)$ & 32.8 & 3.6 & 9.8 & 44.0 & 5.3 & 2.6 & 1.9 \\
\hline Ayu (74 days old) & 3.53 & 2.00 & $1.53(43.4 \%)$ & 32.6 & 4.7 & 3.3 & 48.8 & 4.1 & 6.5 & - \\
\hline Prawn (Post-larvae P-30) & 0.96 & 0.63 & $0.33(34.7 \%)$ & 30.5 & 4.3 & 10.9 & 45.4 & 4.8 & 2.1 & 2.0 \\
\hline \multicolumn{11}{|c|}{$\begin{array}{l}\text {-1 CH (20\%) and TS (20\%) indicate marine Chlorella and Tetraselmis cultured in a water (20\% salinity), respectively. CH (20\%)- } \\
\text { rotifer means B. plicatilis reared with marine Chlorella [CH }(20 \%)] \text {. }\end{array}$} \\
\hline \multicolumn{11}{|c|}{$\begin{array}{l}\text { *2 TL, total lipids; NL, neutral lipids; PL, phospholipids. TL, NL, and PL contents of the food organisms were expressed as } \% \\
\text { of dry weight, and those of the larval fish and post-larval prawn were shown as } \% \text { of fresh weight. } \\
\text { * PE, phosphatidylethanolamine; PS, phosphatidylserine; PI, phosphatidylinositol; PC, phosphatidylcholine; SM, sphingomyelin }\end{array}$} \\
\hline
\end{tabular}

Soybean lecithin comprised $\mathrm{C}_{18: 2 \omega b}$ as the major fatty acids. The major fatty acids of Chlorella

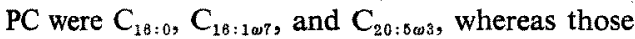
of Tetraselmis $\mathrm{PC}$ were $\mathrm{C}_{18: 0,}, \mathrm{C}_{18: 1 \omega \theta}$, and $\mathrm{C}_{18: 3 \omega 3}$. The PC of $\mathrm{CH}(20 \%)$ - and $\mathrm{CH}(35 \%)$-rotifers involved $\mathrm{C}_{18: 0,}, \mathrm{C}_{18: 2 \omega 6 \text {, }}$ and $\mathrm{C}_{20: 5 \omega 3}$ as the major fatty acids, whereas that of $\operatorname{TS}(20 \%)$-rotifer did $C_{18: 0,}, C_{18: 3 \alpha 3}$, and $C_{20: 4 \omega 3 .}$. The occurrence of high levels of $\mathrm{C}_{20: 4 \omega 3}$ in the PC of TS(20\%)-rotifer suggests the conversion of exogenous $C_{18: 3 \omega 3}$ to $\mathrm{C}_{20: 4 \omega 8}$ in the rotifers fed $\operatorname{TS}(20 \%)$ containing abundance of $\mathrm{C}_{18: 3 \omega 3}$. Fukusho et al. ${ }^{21)}$ also reported that the rotifer cultured with Tetraselmis contained $\mathrm{C}_{18: 3 \omega s}$ as the major fatty acids $(22.4 \%$ of total fatty acids) and lesser amounts of highly unsaturated fatty acids (HUFA) such as $\mathrm{C}_{20: 40 \theta}$ $(5.7 \%)$ and $\mathrm{C}_{20: 5 \omega 3}(5.8 \%)$.

The PC of the red sea bream, knife jaw, Ayu, and prawn contained $\mathrm{C}_{18: 2 \omega 6}, \mathrm{C}_{20: 5 \omega 3}$, and $\mathrm{C}_{22: 8 \omega 3}$ in addition to $C_{16: 0}, C_{18: 0}$, and $C_{18: 1 \omega 8}$ as the prominent fatty acids.

\section{Possible Fatty Acid Combinations in PC}

Table 4 shows the possible fatty acid combinations in PC which were estimated from both the fatty acid compositions of hydrogenated PC and the PC compositions based on total carbons in fatty acyl chains (Table 3). Soybean lecithin was composed of five components with the fatty acid combinations of $\mathrm{C}_{18} \mathrm{C}_{18}, \mathrm{C}_{18} \mathrm{C}_{18}, \mathrm{C}_{14} \mathrm{C}_{22}, \mathrm{C}_{18} \mathrm{C}_{20}$, and $\mathrm{C}_{18} \mathrm{C}_{18}$, the most prominent combinations being $\mathrm{C}_{18} \mathrm{C}_{18}(33.7 \%$ of total $\mathrm{PC})$ and $\mathrm{C}_{18} \mathrm{C}_{18}$ $(59.9 \%$. Because the major fatty acids in the
$C_{18}$ and $C_{18}$ fatty acids were $C_{18: 0}$ and $C_{18: 2 \omega \theta}$ (Table 4), the major fatty acid combinations of $\mathrm{C}_{18} \mathrm{C}_{18}$ and $\mathrm{C}_{18} \mathrm{C}_{18}$ were conceived to be those of $\mathrm{C}_{18: 0} \mathrm{C}_{18: 2 \omega \beta}$ and $\mathrm{C}_{13: 2 \omega \theta} \mathrm{C}_{18: 2 \omega ;}$, respectively. In the similar manner, the major fatty acid combinations of $\mathrm{PC}$ from the food organisms, larval fish, and prawn were estimated (Table 5).

The PC of $\mathrm{CH}(20 \%)$ was mainly composed of three components with the fatty acid combinations of $\mathrm{C}_{16} \mathrm{C}_{16}(22.9 \%), \mathrm{C}_{14} \mathrm{C}_{20}(24 \%)$, and $\mathrm{C}_{10} \mathrm{C}_{20}$ $(39.6 \%)$. The major fatty acid combinations of $\mathrm{C}_{10} \mathrm{C}_{18}$ and $\mathrm{C}_{14} \mathrm{C}_{20}$ could be those of $\mathrm{C}_{19: 0} \mathrm{C}_{18: 1}$ and

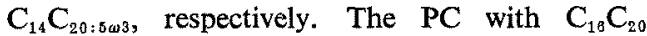
moieties might be those containing $\mathrm{C}_{18: 0} \mathrm{C}_{20: \text { sor }}$ and/or $\mathrm{C}_{10: 1} \mathrm{C}_{20: 5 \omega 3}$. The PC of TS(20\%) consisted of mostly those with fatty acid combinations of $\mathrm{C}_{18} \mathrm{C}_{18}\left(52.6 \%\right.$; mainly $\left.\mathrm{C}_{18: 0} \mathrm{C}_{18: 3 \omega 3}\right), \mathrm{C}_{18} \mathrm{C}_{20}$ $\left(14.2 \%\right.$; mainly $\left.\mathrm{C}_{18: 0} \mathrm{C}_{20: 603}\right)$, and $\mathrm{C}_{18} \mathrm{C}_{18}(16.3 \%$; mainly $\mathrm{C}_{18: 1 \omega \theta} \mathrm{C}_{18: 2 \omega \theta}$ and/or $\mathrm{C}_{18: 1 \omega \theta} \mathrm{C}_{18: 3 \omega 3}$ ). Since the $\mathrm{PC}$ of marine organisms generally contain unsaturated fatty acids at position 2 much more than saturated fatty acids, ${ }^{22-20)}$ the PC of Chlorella and Tetraselmis possibly possess $\mathrm{C}_{20: 5 \omega 3}$ and $\mathrm{C}_{18: 3 \omega^{3}}$ as the fatty acid moieties at position 2 .

The $\mathrm{CH}(20 \% 0)$-rotifer contained the $\mathrm{PC}$ with fatty acid combinations of $\mathrm{C}_{10} \mathrm{C}_{10}(13.1 \%$; mainly $\left.\mathrm{C}_{18: 0} \mathrm{C}_{10: 1}\right), \mathrm{C}_{14} \mathrm{C}_{20}\left(11.8 \%\right.$; mainly $\left.\mathrm{C}_{14: 0} \mathrm{C}_{20: 8 \omega 3}\right)$, $\mathrm{C}_{18} \mathrm{C}_{20} \quad\left(24.6 \%\right.$; mainly $\left.\mathrm{C}_{18: 0} \mathrm{C}_{20: 5 \omega 3}\right), \quad \mathrm{C}_{28} \mathrm{C}_{18}$ $\left(11.8 \%\right.$; mainly $\mathrm{C}_{18: 1 \omega 8} \mathrm{C}_{18: 2 \omega \theta}$ and/or $\left.\mathrm{C}_{18: 0} \mathrm{C}_{18: 2 \omega \theta}\right)$ and $\mathrm{C}_{18} \mathrm{C}_{22} \quad\left(13.7 \%\right.$; mainly $\mathrm{C}_{16: 0} \mathrm{C}_{22: 6 \omega 3}$ and/or $\left.\mathrm{C}_{10: 0} \mathrm{C}_{22: 5 \omega 3}\right)$. The $\mathrm{CH}(35 \%)$-rotifer gave similar fatty acid combinations in $\mathrm{PC}$ to the $\mathrm{CH}(20 \%)$ rotifer, but the former possessed higher levels of 
Table 2. Fatty acid compositions (\%) of phosphatidylcholines from the food organisms, larval fish, and post-larval prawn $P$. japonicus

\begin{tabular}{|c|c|c|c|c|c|c|c|c|c|c|}
\hline Fatty acid & $\begin{array}{l}\text { Soybean } \\
\text { lecithin }\end{array}$ & $\begin{array}{l}\text { Marine } \\
\text { Chlorella }\end{array}$ & $\begin{array}{l}\text { Tetra- } \\
\text { selmis }\end{array}$ & $\begin{array}{c}\mathrm{CH} \\
(20 \%)- \\
\text { rotifer }\end{array}$ & $\begin{array}{c}\mathrm{CH} \\
(35 \%)- \\
\text { rotifer }\end{array}$ & $\begin{array}{c}\text { TS } \\
(20 \%) \text { - } \\
\text { rotifer }\end{array}$ & $\begin{array}{c}\text { Red sea } \\
\text { bream }\end{array}$ & $\underset{\text { jaw }}{\text { Knife }}$ & Ayu & $\begin{array}{l}\text { Prawn } \\
(P-30)\end{array}$ \\
\hline $14: 0$ & 0.13 & 7.94 & 0.86 & 3.51 & 3.20 & 2.14 & 0.96 & 0.71 & 0.57 & 1.05 \\
\hline $14: 1$ & - & 0.53 & - & - & - & - & 0.26 & 0.25 & - & 0.69 \\
\hline $14: 2$ & - & - & - & 0.89 & 0.43 & 0.32 & - & - & 0.10 & 0.44 \\
\hline $14: 3$ & - & 1.39 & 0.30 & 1.48 & 0.49 & 0.84 & 0.21 & 0.40 & 0.18 & - \\
\hline (Sum) & 0.13 & 9.84 & 1.16 & 5.88 & 4.12 & 3.30 & 1.43 & 1.39 & 0.85 & 2.18 \\
\hline $16: 0$ & 16.44 & 18.73 & 26.64 & 18.17 & 20.73 & 26.11 & 23.80 & 19.58 & 20.92 & 16.81 \\
\hline $16: 1 \omega 7$ & - & 22.53 & 5.10 & 9.09 & 8.69 & 4.36 & 4.60 & 3.58 & 2.64 & 2.62 \\
\hline $16: 2 \omega 6$ & - & 0.78 & 0.99 & - & 1.08 & - & 一 & - & - & - \\
\hline $16: 3 \omega 6$ & - & 0.57 & 1.34 & 0.29 & 0.23 & 0.12 & 1.01 & 1.17 & 0.83 & 0.91 \\
\hline $16: 3 \omega 3$ & 0.23 & 0.49 & 0.99 & - & - & 0.40 & 0.57 & 0.92 & 0.26 & 0.24 \\
\hline $16: 4 \omega 3$ & - & 0.17 & 9.58 & - & 0.57 & 1.25 & 0.31 & - & 0.19 & 0.48 \\
\hline (Sum) & 16.67 & 43.27 & 44.64 & 27.55 & 31.30 & 32.24 & 30.29 & 25.25 & 24.84 & 21.06 \\
\hline $18: 0$ & 4.14 & 0.30 & 0.94 & 4.15 & 4.06 & 4.47 & 11.24 & 10.83 & 5.81 & 6.78 \\
\hline $18: 1 \omega 9$ & 12.99 & 2.54 & 11.29 & 5.10 & 8.49 & 6.58 & 14.53 & 13.35 & 14.91 & 14.59 \\
\hline $18: 2 \omega 6$ & 56.35 & 2.53 & 7.71 & 11.05 & 21.40 & 4.38 & 6.37 & 9.15 & 5.52 & 11.26 \\
\hline $18: 3 \omega 6$ & 8.30 & 0.41 & 0.17 & - & - & 0.16 & - & - & - & - \\
\hline $18: 3 \omega^{3}$ & - & 0.11 & 22.47 & - & 1.54 & 19.50 & 0.17 & 0.31 & 0.54 & 1.27 \\
\hline $18: 4 \omega 3$ & - & - & 2.27 & 0.66 & 0.10 & 1.17 & - & - & 0.13 & - \\
\hline (Sum) & 81.78 & 5.89 & 44.85 & 20.90 & 35.59 & 36.26 & 32.31 & 33.64 & 26.91 & 33.90 \\
\hline $20: 0$ & - & - & - & - & - & - & 0.18 & 0.35 & - & 0.22 \\
\hline $20: 1 \omega 9$ & 0.19 & - & 2.16 & 3.52 & 3.18 & 3.65 & 1.16 & 1.15 & 0.57 & 1.34 \\
\hline $20: 2 \omega 6$ & - & - & - & 0.42 & 1.07 & - & 0.55 & 0.50 & 0.17 & 0.56 \\
\hline $20: 3 \omega 6$ & - & 0.53 & 0.18 & 2.81 & 1.97 & 0.99 & 0.65 & 0.49 & 0.18 & 0.46 \\
\hline $20: 3 \omega 3$ & - & 5.13 & 0.64 & 3.86 & 2.74 & 2.40 & 3.53 & 2.57 & 3.76 & 2.82 \\
\hline $20: 4 \omega 6$ & - & - & 0.89 & 4.26 & 2.71 & 8.17 & 0.44 & 0.56 & 0.55 & 0.90 \\
\hline $20: 5 \omega 3$ & 0.50 & 34.05 & 4.26 & 14.72 & 8.52 & 5.12 & 6.48 & 6.01 & 11.18 & 13.87 \\
\hline (Sum) & 0.69 & 39.71 & 8.13 & 29.59 & 20.19 & 20.33 & 12.99 & 11.63 & 16.41 & 20.17 \\
\hline $22: 0$ & - & - & 0.01 & - & - & - & - & - & - & - \\
\hline $22: 1 \omega 9$ & - & 0.10 & 0.42 & 4.63 & - & 3.41 & 0.97 & 0.74 & 0.51 & 1.10 \\
\hline $22: 2 \omega 6$ & - & - & - & - & 2.81 & - & 0.06 & - & - & - \\
\hline $22: 3 \omega 6$ & - & 0.13 & - & 0.57 & 0.29 & 0.34 & - & - & 0.11 & - \\
\hline $22: 3 \omega 3$ & - & - & - & 0.45 & - & 0.12 & 0.35 & 0.19 & 0.33 & - \\
\hline $22: 4 \omega 3$ & - & 0.41 & 0.49 & 2,98 & 1.74 & 2.21 & 1.16 & 0.90 & 0.66 & 1.07 \\
\hline $22: 5 \omega 3$ & 0.11 & 0.12 & 0.18 & 5.12 & 2.89 & 0.88 & 4.20 & 1.41 & 2.00 & 0.28 \\
\hline $22: 6 \omega 3$ & 0.62 & 0.54 & 0.13 & 2.26 & 1.07 & 0.91 & 16.24 & 24.85 & 27.38 & 20.25 \\
\hline (Sum) & 0.73 & 1.30 & 1.22 & 16.01 & 8.80 & 7.87 & 22.98 & 28.09 & 30.99 & 22.70 \\
\hline
\end{tabular}

the PC having $\mathrm{C}_{18} \mathrm{C}_{18}\left(32.9 \%\right.$, mainly $\left.\mathrm{C}_{18: 0} \mathrm{C}_{18: 2 \omega 0}\right)$ moieties and lower levels of the PC having $\mathrm{C}_{18} \mathrm{C}_{20}$ $(12.3 \%)$ and $\mathrm{C}_{14} \mathrm{C}_{20}$ moieties than the latter. The TS(20\%o)-rotifer involved mainly the $\mathrm{PC}$ with fatty acid combinations of $\mathrm{C}_{18} \mathrm{C}_{18}(43.8 \%$; mainly $\left.\mathrm{C}_{18: 0} \mathrm{C}_{18: 3 \omega 3}\right)$ and $\mathrm{C}_{18} \mathrm{C}_{18} \quad(14.7 \%$; mainly $\mathrm{C}_{18: 0} \mathrm{C}_{18: 3 \omega 3}$ and/or $\mathrm{C}_{18: 1 \omega 8} \mathrm{C}_{18: 3 \omega 3}$ ). As the fatty acid moieties at position 2 of $\mathbf{P C}$, the TS-rotifer was thus likely to contain $\mathrm{C}_{18: 303}$ in contrast to

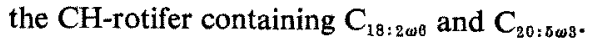

The PC of red sea bream consisted of mainly the components with fatty acid combinations of
$\mathrm{C}_{18} \mathrm{C}_{18} \quad\left(19.4 \%\right.$; mainly $\left.\mathrm{C}_{10: 0} \mathrm{C}_{18 ; 1 \omega \theta}\right), \quad \mathrm{C}_{10} \mathrm{C}_{20}$ $\left(15.5 \%\right.$; mainly $\left.\mathrm{C}_{18: 0} \mathrm{C}_{20: 5 \omega 3}\right), \mathrm{C}_{18} \mathrm{C}_{22} \quad(21.9 \%$; mainly $\left.\mathrm{C}_{18: 0} \mathrm{C}_{22: \theta \omega s}\right)$, and $\mathrm{C}_{18} \mathrm{C}_{22}$ (14.8\%; mainly $\mathrm{C}_{18: 0} \mathrm{C}_{22: 60 / 8}$ and/or $\left.\mathrm{C}_{18: 1008} \mathrm{C}_{22: \text { a } 108}\right)$. The knife jaw gave similar fatty acid combinations in $\mathrm{PC}$ to the red bream, although the former contained higher levels of the $\mathrm{PC}$ having $\mathrm{C}_{18} \mathrm{C}_{22}(31.0 \%)$ than the latter. The PC of Ayu was composed of largely the components with fatty acid combinations of $\mathrm{C}_{18} \mathrm{C}_{2 \mathrm{~g}}$ $\left(21.0 \%\right.$; mainly $\left.\mathrm{C}_{18: 0} \mathrm{C}_{22: 8 \omega 3}\right)$ and $\mathrm{C}_{18} \mathrm{C}_{22}(28.5 \%$; mainly $\mathrm{C}_{18: 1 \omega \theta} \mathrm{C}_{22: \theta \omega 3}$ ). The prawn revealed similar fatty acid combinations in $\mathrm{PC}$ to the larval fish 
Table 3. Total carbon numbers in fatty acyl chains of phosphatidylcholines (PC) from the food organisms, larval fish, and post-larval prawn $P$. japonicus

\begin{tabular}{lrrrrrrr}
\hline \multirow{2}{*}{ Organism* } & \multicolumn{6}{c}{ Total carbon number $\%$ of total fatty acyl chains of PC) } \\
\cline { 2 - 8 } & \multicolumn{1}{c}{$\mathrm{C}_{32}$} & \multicolumn{1}{c}{$\mathrm{C}_{34}$} & \multicolumn{1}{c}{$\mathrm{C}_{38}$} & $\mathrm{C}_{38}$ & $\mathrm{C}_{40}$ & $\mathrm{C}_{42}$ & $\mathrm{C}_{44}$ \\
\hline Soybean lecithin & 4.3 & 33.7 & 62.0 & - & - & - & - \\
Marine Chlorella [CH (20\%)] & 22.9 & 24.3 & 42.6 & 5.7 & 4.5 & - & - \\
Tetraselmis [TS (20\%)] & 3.8 & 52.6 & 30.4 & 9.8 & 3.4 & - & - \\
CH (20\%)-rotifer & 13.1 & 18.7 & 36.4 & 22.6 & 5.6 & 2.5 & 1.3 \\
CH (35\%)-rotifer & 10.4 & 32.9 & 33.4 & 16.5 & 3.7 & 2.5 & 0.7 \\
TS (20\%)-rotifer & 6.3 & 50.7 & 29.3 & 11.4 & 2.0 & 0.2 & - \\
\hline Red sea bream & 6.5 & 19.4 & 25.9 & 24.0 & 12.8 & 7.8 & 3.5 \\
Knife jaw & 2.0 & 14.2 & 20.5 & 28.2 & 31.0 & 2.5 & 1.6 \\
Ayu & 0.7 & 5.7 & 14.7 & 30.0 & 37.0 & 7.9 & 4.1 \\
Prawn & 6.5 & 11.0 & 21.7 & 25.2 & 25.3 & 6.6 & 3.6 \\
\hline
\end{tabular}

- See Table 1 for abbreviations.

examined, but it contained considerably large proportions of the $\mathrm{PC}$ having fatty acid combinations of $\mathrm{C}_{18} \mathrm{C}_{20}\left(22.7 \%\right.$; mainly $\mathrm{C}_{18: 1 \omega \theta} \mathrm{C}_{20: 5 \omega 8}$ and/or $\left.\mathrm{C}_{18: 2 \omega 0} \mathrm{C}_{20: 503}\right)$ besides $\mathrm{C}_{10} \mathrm{C}_{20}(20.1 \%)$ and $\mathrm{C}_{18} \mathrm{C}_{22}(25.3 \%)$.

\section{Discussion}

The addition of PL, specifically PC and PI, has been shown to be indispensable for sustaining good growth and survival of the larval fish. ${ }^{1-4)}$ In the case of the larval Ayu, the incidence of malformation, especially scoliosis and twist of jaw, was also markedly reduced by the supplement of PL such as PC to diets. ${ }^{4}$ But, a basic question to be answered is why dietary PL are required for growth and survival of the larval fish in contrast to the case of grown fish. We thought that the detailed analysis of PL components of both food organisms and larval fish might give some clue to the mechanism by which dietary PL enhance the growth and survival of larval fish, because the practical seed production of fish has been sucessfully performed using the live food such as the rotifer and Artemia nauplii.

The results of the present study showed that the compositions ( $\%$ ) of PL classes were not notably different among the animals examined. PC and PE were the major PL classes in the rotifers, larval fish, prawn, and micro-algae, Chlorella and Tetraselmis. But, the fatty acid compositions and molecular species of PC differed among the organisms examined (Tables 4 and 5). The larval fish such as the red sea bream, knife jaw, and Ayu contained the PC including w3-highly unsaturated fatty acids (HUFA) as the fatty acid moieties; the major PC being those with fatty acid combinations of $\mathrm{C}_{18: 0} \mathrm{C}_{20: 5 \omega 3}, \mathrm{C}_{18: 0} \mathrm{C}_{22: 8 \omega 3}$, $\mathrm{C}_{18: 0} \mathrm{C}_{22: 643}$, and/or $\mathrm{C}_{18: 1 \text { in }} \mathrm{C}_{22: 0 \times 8}$. The prawn also possessed the $\mathrm{PC}$ including $\mathrm{C}_{20: 5 \omega 3}$ or $\mathrm{C}_{22: 8 \omega 3}$ as the major fatty acid moieties. On the other hand, the rotifers contained the $\mathrm{PC}$ with fatty acid combinations of $\mathrm{C}_{18: 0} \mathrm{C}_{20: 508,}, \mathrm{C}_{18: 0} \mathrm{C}_{18: 2 \omega \theta}$, $\mathrm{C}_{18: 0} \mathrm{C}_{18: 2 \omega \theta}$, and/or $\mathrm{C}_{18: 1, \theta \theta} \mathrm{C}_{18: 2 \omega \theta}$ besides $\mathrm{C}_{18: 0} \mathrm{C}_{18: 1}$ as the prominent components. Since fish are incapable of de novo synthesis of $\omega 6$ - and $\omega 3$ series of fatty acids, ${ }^{2 \theta, 27)}$ the PC including $\omega 3$ HUFA moieties in the larval fish are conceived to be derived from dietary sources. Therefore, the PC including $\omega 3$-HUFA moieties may be necessary for the larval fish if the rate of biosynthesis of such a PL from free fatty acids does not satisfy metabolic demands. In fact, Kanazawa et al. ${ }^{* 3}$ have shown that the PC fraction containing abundance of $\omega 3$-HUFA from the bonito eggs was highly effective in improving the growth and survival of the larval Ayu. Considering these data and information, we assume that the PC containing 13 -HUFA occurring in the larval fish examined may originate mainly from the PC having fatty acid combination of $\mathrm{C}_{10: 0} \mathrm{C}_{20: 5 \omega 3}$ which was found in the rotifers.

The following may be postulated for the reason why dietary PL enhance the growth and survival of larval fish: (1) Dietary PL may accelerate the assimilation of dietary lipids such as triglycerides in the larval fish having an undeveloped digestive system; or (2) the larval fish may possess a limited ability for the biosynthesis of some PL which are important in the formation of cellular components and lipoproteins responsible for the lipid transport in the body, then require dietary sources of specific PL. Further work is required to clarify the nutritional role of dietary PL in larval fish. 
Table 4. Possible fatty acid combinations in phosphatidylcholines from the food organisms, larval fish, and post-larval prawn $P$. japonicus

\begin{tabular}{|c|c|c|c|c|c|c|c|c|c|c|c|c|c|}
\hline \multirow{3}{*}{ Organisms* } & \multicolumn{13}{|c|}{ Total carbon number and possible combination of fatty acids (mol. $\%$ ) } \\
\hline & \multicolumn{2}{|c|}{$\mathrm{C}_{32}$} & \multicolumn{2}{|c|}{$C_{34}$} & \multicolumn{3}{|c|}{$\mathrm{C}_{36}$} & \multicolumn{2}{|c|}{$\mathrm{C}_{38}$} & \multicolumn{2}{|c|}{$\mathrm{C}_{40}$} & \multirow{2}{*}{$\frac{\mathrm{C}_{42}}{\mathrm{C}_{20} \mathrm{C}_{22}}$} & \multirow{2}{*}{$\begin{array}{r}\mathbf{C}_{44} \\
\mathrm{C}_{22} \mathrm{C}_{2} \\
\end{array}$} \\
\hline & $\mathrm{C}_{14} \mathrm{C}_{18}$ & $\mathrm{C}_{10} \mathrm{C}_{1 \mathrm{~B}}$ & $\mathrm{C}_{14} \mathrm{C}_{20}$ & $\mathrm{C}_{19} \mathrm{C}_{18}$ & $\mathrm{C}_{14} \mathrm{C}_{22}$ & $\mathrm{C}_{10} \mathrm{C}_{20}$ & $\mathrm{C}_{18} \mathrm{C}_{18}$ & $\mathrm{C}_{10} \mathrm{C}_{22}$ & $\mathrm{C}_{18} \mathrm{C}_{20}$ & $\mathrm{C}_{18} \mathrm{C}_{22}$ & $\mathrm{C}_{20} \mathrm{C}_{20}$ & & \\
\hline Soybean lecithin & - & 4.3 & - & 33.7 & 1.2 & 1.0 & 59.9 & - & - & - & - & - & - \\
\hline Marine Chlorella $[\mathrm{CH}(20 \%)]$ & - & 22.9 & 24.3 & - & - & 39.6 & 4.4 & 2.2 & 5.7 & - & 4.5 & - & - \\
\hline Tetrasalmis $[\mathrm{TS}(20 \%)]$ & 1.8 & 2.0 & - & 52.6 & - & 14.2 & 16.3 & 2.2 & 7.7 & - & 3.3 & - & - \\
\hline $\mathrm{CH}(20 \%)$-rotifer & - & 13.1 & 11.8 & 6.9 & - & 24.6 & 11.8 & 13.7 & 8.9 & - & 5.8 & 2.5 & 1.3 \\
\hline $\mathrm{CH}(35 \%)$-rotifer & - & 10.4 & - & 32.9 & 6.4 & 12.3 & 14.7 & 8.2 & 8.3 & - & 3.7 & 2.5 & 0.7 \\
\hline TS(20\%o)-rotifer & - & 6.3 & 7.0 & 43.8 & - & 14.6 & 14.7 & 10.9 & 0.5 & 2.0 & - & 0.3 & - \\
\hline Red sea bream & 3.0 & 3.6 & - & 19.4 & - & 15.5 & 10.4 & 21.9 & 2.2 & 14.8 & - & 7.8 & 3.6 \\
\hline Knife jaw & 2.2 & 0.1 & - & 14.2 & - & 11.5 & 9.0 & 20.3 & 8.0 & 31.0 & - & 2.5 & 1.6 \\
\hline Ayu & 1.5 & - & - & 5.7 & - & 8.3 & 5.2 & 21.0 & 9.0 & 28.5 & 5.3 & 7.9 & 4.1 \\
\hline Prawn & 2.8 & 3.8 & - & 11.0 & - & 20.1 & 3.5 & 5.5 & 22.7 & 25.4 & - & 6.6 & 3.6 \\
\hline
\end{tabular}

- See Table 1 for abbreviations. 
Table 5. Presumed molecular species of the main PC in the food organisms, larval fish, and postlarval prawn $P$. japonicus

\begin{tabular}{|c|c|}
\hline Organism & Molecular species \\
\hline $\begin{array}{l}\text { Soybean lecithin } \\
\text { Marine Chlorella }[\mathrm{CH}(20 \%)] \\
\text { Tetraselmis [TS }(20 \%)] \\
\text { CH }(20 \%) \text {-rotifer } \\
\text { CH }(35 \%) \text {-rotifer } \\
\text { TS }(20 \%) \text {-rotifer }\end{array}$ & 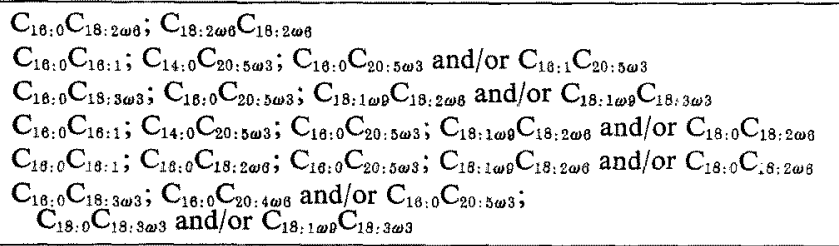 \\
\hline $\begin{array}{l}\text { Red sea bream } \\
\text { Knife jaw } \\
\text { Ayu } \\
\text { Prawn }\end{array}$ & 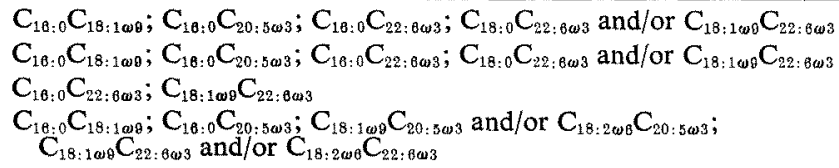 \\
\hline
\end{tabular}

\section{Acknowledgements}

We wish to thank the members of the Fisheries Experimental Station of Oita Prefecture for kindly providing the larval fish. The research was supported in part by a grant from the Fisheries Agency of Japan.

\section{References}

1) A. Kanazawa, S. Teshima, S. Inamori, S. Sumida, and T. Iwashita: Mem. Fac. Fish. Kagoshima Univ., 31, 185-192 (1982).

2) A. Kanazawa, S. Teshima, S. Inamori, and H. Matsubara: Mem. Fac. Fish. Kagoshima Univ., 32, 109-114 (1983).

3) A. Kanazawa, S. Teshima, T. Kobayashi, M. Takae, T. Iwashita, and R. Uehara: Mem. Fac. Fish. Kagoshim Univ, 32, 115-120 (1983).

4) A. Kanazawa, S. Teshima, S. Inamori, T. Iwashita, and A. Nagao: Mem. Fac. Fish. Kagoshima Univ., 30, 301-309 (1981).

5) A. Kanazawa: in "Proceedings of 2nd International Conference on Aquaculture Nutrition" (ed. by G.D. Pruder, C.J. Langdon, and D.E. Conklin), Special Publication No. 2, World Mariculture Society, Louisiana State University, Baton Rouge, 1982, pp. 87-105.

6) S. Teshima, A. Kanazawa, H. Sasada, and M. Kawasaki: Mem. Fac. Fish. Kagoshima Univ., 31, 193-199 (1982).

7) A. Kanazawa, S. Teshima, and M. Sakamoto: Aquaculture, 50, 39-49 (1985).

8) D. E. Conklin, L. R. D'Abramo, C. E. Bordner, and N.A. Baum: Aquaculture, 21, 243-250 (1980).

9) L. R. D'Abramo, C. E. Bordner, D. E. Conklin, and N. A. Baum: $\dot{J}$. Nutr., 111, 425-431 (1981).

10) S. Teshima, A. Kanazawa, and Y. Kakuta:
Nippon Suisan Gakkaishi, 52, 155-158 (1986).

11) S. Teshima, A. Kanazawa, and Y. Kakuta: Nippon Suisan Gakkaishi, 52, 159-163 (1986).

12) S. Teshima, A. Kanazawa, and Y. Kakuta: Nippon Suisan Gakkaishi, 52, 519-524 (1986).

13) S. Teshima, A. Kanazawa, and Y. Kakuta: Nippon Suisan Gakkaishi, 52, 719-723 (1986).

14) S. Fujita: in "Growth and Feeding of Larval Fish" (ed. by Japan. Soc. Sci. Fish.), Suisangaku Series No. 8, Koseisha-koseikaku, Tokyo, 1975, pp. $100-113$.

15) T. Watanabe: Yukagaku, 31, 77-90 (1982).

16) H. Hirata: Min. Rev. Data File Fish. Res., Kagoshima Univ., 1, 27-46 (1980).

17) A. Kanazawa and S. Teshima: Yoshoku, 20, 97101 (1983).

18) E. G. Bligh and W. J. Dyer: Can. J. Biochem. Physiol., 37, 911-917 (1959).

19) S. Teshima and A. Kanazawa: Nippon Suisan Gakkaishi, 49, 957-962 (1983).

20) T. Ohshima, S. Wada, and C. Koizumi: Nippon Suisan Gakkaishi, 49, 123-130 (1983).

21) K. Fukusho, M. Okauchi, S. Nuraini, A. Tsujigado, and T. Watanabe: Nippon Suisan Gakkaishi, 50, 1439-1444 (1984).

22) D. B. Menzel and H.S. Olcott: Biochim. Biophys. Acta, 84, 133-139 (1964).

23) R. Wood and F. Snyder: Arch. Biochem. Biophys., 131, 478-494 (1969).

24) K. Takahashi, F. Cabling, and K. Zama: Bull. Fac. Fish. Hokkaido Univ., 29, 386-391 (1978).

25) A. Kuksis: in "Progress in the Chemistry of Fats and Other Lipids" (ed. by R. T. Holman), Vol, 12, Pergamon Press, Oxford, New York, Toronto, 1972, pp. 105-111.

26) J. R. Sargent: in "Biochemical and Biophysical Perspective in Marine Biology" (ed. by D. C. Malins and J. R. Sargent), Vol. 3, Academic Press, London, New York, and San Francisco, 1976, pp. 149-212.

27) M. Kayama: Yukagaku, 32, 719-725 (1983). 